\title{
NIH concede part of Rifkin suit
}

\section{Washington}

THE US government has quietly conceded a major claim in the lawsuit brought by antigenetic-engineering activist Jeremy Rifkin to halt field trials of recombinant microorganisms.

Last May (see Nature 24 May, p.296), US District Judge John Sirica placed a preliminary injunction on all such experiments supported by the federal government, and in particular an experiment planned by Steven Lindow of the University of California at Berkeley to test the ability of genetically-engineered bacteria to protect potato plants against frost damage. Sirica ruled that in approving that experiment, the Recombinant DNA Advisory Committee (RAC) of the National Institutes of Health (NIH) had failed to satisfy two legal requirements: it had not conducted a formal environmental assessment of the experiment, and it had not prepared a much lengthier environmental impact statement on the entire programme of environmental release of recombinant DNA.

In an appeal filed with the US Circuit Court of Appeals in Washington, the government has now indicated that it will prepare an environmental assessment of the Lindow experiment and any others involving release to the environment. The government is continuing to appeal against Sirica's finding that what is called a "programmatic impact statement"' is required. In a separate appeal, the University of Cali- fornia is challenging both requirements.

According to Bernard Talbot, deputy director of the National Institute of Allergy and Infectious Diseases, the NIH institute that contains RAC, attorneys of the Department of Justice had pressed NIH to drop its opposition to the environmental assessment requirement, feeling that the government's case would be much stronger if it were limited to the issue of the future programme. The government argues that there is in fact no "programme" of release to the environment, and that the proposed experiments are so widely different that a case-by-case approach is the only one possible.

The Office of Recombinant DNA Activities at NIH has already begun to compile an environmental assessment of the Lindow experiment, but NIH officials make it clear that they consider the exercise meaningless, fulfilling a formal legal requirement without adding anything of substance. The Lindow experiment was debated at two public meetings of RAC, and was revised in response to concern expressed by the committee. NIH appear to be hedging their bets by agreeing to go ahead with the environmental assessments at this stage. And with the University of California continuing to press the full appeal, the government clearly had little to lose.

Although Sirica's injunction specifically exempted experimental proposals from commercial companies - which have been

\section{Gloomy outlook for young neuroscientists}

Los Angeles

As the US Society for Neuroscience held its 14th annual meeting in Anaheim from 10 to 15 October, there was talk in the corridors of great frustrations and dashed expectations.

But the subject did not revolve around difficult research questions in neuroscience. Rather, it applied to scores of young scientists who are dropping out of the discipline because financial support and job prospects are woefully inadequate.

Neuroscientists are not the only group to complain about support for the students they train. But, argued Dr Dominick Purpura, last year's society president, because neuroscience is reaping great intellectual rewards, it is attracting many of the brightest and best students in US universities.

Once trained, the young neuroscientist is faced with "incredible competition", Dr Purpura said. "Many universities will take on a young scientist for one or two years, whereupon the scientist must provide his or her own financial support. But the young are competing against established people for limited funds. There is so much compe-

tition that people are disheartened and drop out." The job placement centre at the meeting interviewed 1,200 candidates for fewer than 250 jobs, mostly postdoctoral appointments without long-term security.

Unfortunately, few of you will be given the opportunity to use

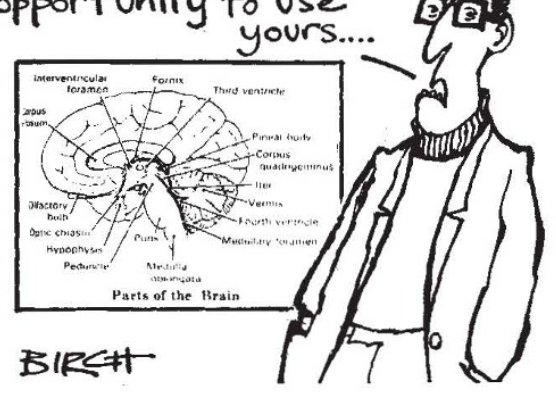

The National Institutes of Health and the National Science Foundation together support 85 per cent of research in biology and biomedicine, Dr Purpura said. "They are $\mathbf{\$ 5 0}$ to $\mathbf{\$ 1 0 0}$ million short in grants that might allow young neuroscientists to get a start.
What, no uranium?

\section{Canberra}

AUSTRAlian exports of uranium oxide to France are likely to stop for at least two years. The Australian Minister for Resources and Energy, Senator Walsh, announced last month that the first eight shipments of yellowcake that were to have been sent to the French power company Electricité de France under a contract with the Nabarlek uranium producer, Queensland Mines Limited, will be deferred because of the continuation of nuclear testing at the French underground site at Muroroa Atoll, in the south central Pacific.

This is in line with the Australian government's ban on uranium sales to France confirmed during the Labor Party's national conference in Canberra in July, when a vote to continue mining and export of uranium was carried (see Nature 2 August, p.354). The first shipment (due in October) would have been 100 tonnes of yellowcake valued at \$A6 million. The Australian government has agreed to purchase the first eight contracted shipments at the original price, but Queensland Mines is obliged to repurchase the uranium "if circumstances permit"'. This is interpreted to mean if and when the French stop testing nuclear weapons in the Pacific.

Jeffrey Sellar

submitting them to RAC for approval on a voluntary basis only - NIH director James Wyngaarden has ordered that environmental assessments be carried out for these as well. At its June meeting, RAC approved two commercial proposals from Advanced Genetic Sciences (AGS) almost identical to the Lindow experiment. Once the Lindow document is completed, it should be a quick matter to prepare for the AGS proposal, and that experiment should be clear to go ahead by next spring.

The appeals court is scheduled to hear the case on 5 December. Although the appeal is technically on the preliminary injunction only, for practical purposes the court's decision will decide the entire case. If the appeals court upholds Sirica's decision, the government will probably concede the case rather than let it drag on to a near-certain outcome.

Rifkin was notably unsucessful on another front last week, RAC unanimously rejected his proposal to ban all transfers of genetic material from one mammalian species to the germline of another. The committee noted the benefits that such research holds for the study of cancer and other diseases. Researchers at the University of Pennsylvania have already successfully inserted the gene coding for human growth hormone into mice embryos, and are planning similar experiments on sheep; RAC also noted the possible benefits that such research would bring in more efficient food production.

Stephen Budiansky 